\title{
'n Inleidende woord
}

\section{Hierdie Aflewering van die HTS word opgedra aan professor BJ Engelbrecht by geleentheid van aanvaarding van emeritaat}

Die tagtigjarige geskiedenis van ons Universiteit kan inderdaad in etlike tydvakke verdeel word. Maar gewis vir elke periode, ongeag die uitgangspunt of maatstaf, was daar uitsonderlike persoonlikhede: soos professor Ben Engelbrecht by uitnemendheid nou reeds geword het!

Barend Jacobus Engelbrecht laat diep spore na wanneer hy vir oulaas die Universiteitsdeur agter hom sluit. Dit begin as student, in 1941, en lei hom deur sy opleidingsjare in Afdeling A van ons Fakulteit Teologie en ook elders tot by legitimasie, in November 1946. Daar was ook 'n tydperk van doktorale studie in Nederland, waar hy aan die Rijksuniversiteit te Groningen in die Teologie promoveer, asook'n termyn aan die Universiteit van Basel in Switzerland.

Aldus toegerus, maar ook na enkele jare in die bediening, word professor Engelbrecht aangestel as hoogleraar en departementshoof vir Sistematiese Teologie in 1952, die pos wat hy met sy aftrede vanjaar na 36 jaar van diepe toewyding neerlê. Sy pligte en dienslewering was nie tot 'n leeropdrag beperk nie, want onder meer as Dekaan vir sy Afdeling van die Fakulteit tree hy 17 jaar lank op en in die Universiteitsraad dien hy vanaf 1972 tot 1987.

Ben Engelbrecht sal allereers onthou word vir sy onderskeidende menseienskappe: wellewendheid in elke opsig, gekombineer met buitengewone gawes van intellek en veelsydigheid. Dit het hom trouens 'n geliefde persoonlikheid gemaak, en ook iemand wie se mening oor 'n saak dikwels ingewin en met vrug gebruik is. Trouens deur sowel studente as kollegas is hy altoos hoog geag, vir uitleg wat getuig van ernstige en tegelyk diepsinnige kennis en insig.

Met die aftrede van professor Engelbrecht kom ons andermaal aan die einde van 'n tydvak. Vir my was hy onder meer die laaste persoonlike band met die Ou Letteregebou waar hy self onderrig ontvang, en enduit tot die finale ontruiming van dié fasiliteit klasgegee het. As blyk van ons groot waardering vir sy en sý tydgenote se aandeel in die skepping van 'n trotse tradisie sal die betrokke lesingsaal dan ook as 'n sigbare skakel met die verlede vir die nageslag behoue bly. Dat professor Engelbrecht se vertrek nietemin 'n opsigtelike leemte op die kampus van die Universiteit van Pretoria gaan laat, ly geen twyfel nie!

Prof DM Joubert

ONDERKANSELIER EN REKTOR

Universiteit van Pretoria 


\section{LYS VAN MEDEWERKERS IN HIERDIE AFLEWERING}

Prof dr DM Joubert, Die Rektor, Universiteit van Pretoria, 0002 Pretoria.

Prof dr JP Oberholzer, Die Dekaan, Fakulteit Teologie (Afd A), Universiteit van Pretoria, 0002 Pretoria.

Prof dr AC Barnard, Departement Praktiese Teologie (Afd B), Universiteit van Pretoria, 0002 Pretoria.

Dr J Buitendag, Weslaan 300, Ruiterhof, 2194 Randburg.

Prof dr TFJ Dreyer, Departement Praktiese Teologie (Afd A), Universiteit van Pretoria, 0002 Pretoria.

Prof dr JH Koekemoer, Sentrum vir Voortgesette Teologiese Toerusting, Fakulteit Teologie (Afd A), Universiteit van Pretoria, 0002 Pretoria.

Prof dr PJT Koekemoer, Departement Dogmatiek en Christelike Etiek, Hervormde Teologiese Opleiding te Klipdrif, Privaatsak X2012, 0400 Hammanskraal.

Prof dr Adrio König, Departement Sistematiese Teologie, Universiteit van Suid-Afrika, Posbus 392, 0001 Pretoria.

Dr RM Naudé, Posbus 13599, 0129 Sinoville, Pretoria.

Prof dr GMM Pelser, Departement Nuwe-Testamentiese Wetenskap (Afd A), Universiteit van Pretoria, 0002 Pretoria.

Prof dr AD Pont, Departement Kerkgeskiedenis (Afd A), Universiteit van Pretoria, 0002 Pretoria.

Prof dr PC Potgieter, Departement Dogmatologie, Fakulteit Teologie, Universiteit van die Oranje-Vrystaat, Posbus 339, 9300 Bloemfontein.

Dr DJ Smith, Posbus 16248, 0116 Pretoria-Noord.

Dr IWC van Wyk, Plettenbergstraat 9, Dan Pienaar, 9301 Bloemfontein.

Prof dr JH van Wyk, Hammanskraalse Teologiese Skool van die Gereformeerde Kerke, Posbus 59, 0400 Hammanskraal.

Prof dr GC Velthuysen, Departement Dogmatiek en Christelike Etiek (Afd A), Universiteit van Pretoria, 0002 Pretoria.

Prof dr PM Venter, Departement Bybelkunde (Afd A), Universiteit van Pretoria, 0002 Pretoria.

Prof dr CJ Wethmar, Departement Dogmatiek en Christelike Etiek (Afd B), Universiteit van Pretoria, 0002 Pretoria. 